\title{
Bacillus thuringiensis B1(2015b) is a Gram-Positive Bacteria Able to Degrade Naproxen and Ibuprofen
}

\author{
Ariel Marchlewicz • Dorota Domaradzka • \\ Urszula Guzik • Danuta Wojcieszyńska
}

Received: 19 January 2016 / Accepted: 16 May 2016/Published online: 25 May 2016

(C) The Author(s) 2016. This article is published with open access at Springerlink.com

\begin{abstract}
A Gram-positive bacterium, designated as strain B1(2015b), was isolated from the soil of the chemical factory "Organika-Azot" in Jaworzno, Poland. On the basis of $16 \mathrm{~S}$ rRNA gene sequence analysis, the isolated strain was classified as a Bacillus thuringiensis species. Strain B1(2015b) is able to degrade ibuprofen and naproxen, however, these compounds are not sufficient carbon sources for this strain. In the presence of glucose, Bacillus thuringiensis B1(2015b) degrades ibuprofen and naproxen with higher efficiency. Twenty milligrams per liter of ibuprofen was degraded within 6 days and $6 \mathrm{mg} \mathrm{l}^{-1}$ of naproxen was removed within 35 days. Simultaneously, the growth of the bacterial culture was observed. The obtained results suggest that Bacillus thuringiensis B1(2015b) appears to be a powerful and useful tool in the bioremediation of nonsteroidal anti-inflammatory drugs-contaminated environment.
\end{abstract}

Keywords Bacillus · Naproxen · Ibuprofen · Biodegradation

\footnotetext{
A. Marchlewicz · D. Domaradzka · U. Guzik ·

D. Wojcieszyńska $(\bowtie)$

Department of Biochemistry, Faculty of Biology and Environmental Protection, University of Silesia in Katowice, Jagiellońska 28, 40-032 Katowice, Poland e-mail: danuta.wojcieszynska@us.edu.pl
}

\section{Introduction}

Non-steroidal anti-inflammatory drugs (NSAIDs) enter the environment as a result of pharmaceutical industry activity and the improper disposal of unused or expired drugs, waste generated in hospitals and stock-raising farms (Wu et al. 2012). In recent years, an increasing intake of the over-the-counter drugs such as ibuprofen, naproxen, paracetamol, ketoprofen, diclofenac, and acetylsalicylate has been observed (Wojcieszyńska et al. 2014; Domaradzka et al. 2015). Ibuprofen is the third most highly consumed pharmaceutical in the world (Murdoch and Hay 2015). For example, sale of ibuprofen in Poland and Germany reached 58 tonnes in 2000 and 345 tonnes in 2001, respectively (Nikolaou et al. 2007; Styszko et al. 2010). In 2000, 35 tonnes of naproxen were consumed in England (Nikolaou et al. 2007). This drug belongs to the most frequently detected pharmaceutical in the aquatic environment (Grenni et al. 2013). Although ibuprofen and naproxen are detected in surface water, ground water or even drinking water at a concentration within the $\mathrm{ng}^{-1}$ to $\mu \mathrm{g} \mathrm{l}^{-1}$ range, they may accumulate in aquatic organisms ( $\mathrm{Li}$ et al. 2015a, b; Jeffries et al. 2015). The concentration of ibuprofen determined in the wild fish plasma and bile samples was 100 to 1000 -fold higher than in water (Jeffries et al. 2015). It was also shown that ibuprofen, as a nonselective cyclooxygenase inhibitor, exhibits ecotoxic effects in fish mainly through the endocrine disruption (Yu et al. 2006). In contrast, photoderivatives of naproxen tends to be ecotoxic in acute and chronic conditions (Marotta et al. 2013).

In the environment, naproxen and ibuprofen may undergo sorption, desorption, biotransformation, and abiotic transformation (Lahti and Oikari 2011). The physico-chemical transformations lead to the formation 
of more toxic intermediates (Marotta et al. 2013; Li et al. 2015a). Therefore, bioremediation processes are an attractive alternative to these methods. Bioremediation strategies are cost-effective and enable the mineralization of NSAIDs into the safer products (Ahmed et al. 2001). However, these pharmaceuticals are difficult to biodegrade, and the efficiency of these processes is not satisfactory (Rodriguez-Rodriguez et al. 2010; Li et al. $2015 b$ ). The activated sludge process is used to treat the wastewaters containing non-steroidal anti-inflammatory drugs, but the removal of these drugs has been found to be incomplete (Rodarte-Morales et al. 2011). There is a need to isolate microorganisms with a high capacity for non-steroidal anti-inflammatory drug degradation. However, until now, only a few pure bacterial strains have been described to be able to degrade ibuprofen or naproxen. Murdoch and Hay $(2005,2015)$ described Variovorax Ibu-1 and Sphingomonas Ibu-2 engaged in the degradation of ibuprofen. Probably, degradation of ibuprofen by these strains occurs through catechol derivatives and the meta ring-fission (Murdoch and Hay 2005, 2015). During the degradation of ibuprofen by lignolytic bacteria Nocardia sp. NRRL 5646 formation of two metabolites, ibuprofenol and ibuprofenol acetate was observed (Chen and Rosazza 1994). Only one bacterial strain able to degrade naproxen was described. Stenotrophomonas maltophilia KB2 degrades this drug through the hydroxylation of the derivative of naproxen to hydroxyquinol, which is then cleaved by hydroxyquinol 1,2-dioxygenase (Wojcieszyńska et al. 2014).

Due to poor knowledge about the metabolism of the non-steroidal anti-inflammatory drugs in the environment, it is necessary to search for new pure bacterial strains that are able to degrade these compounds. In this study, the isolation and characterization of a Grampositive Bacillus thuringiensis B1(2015b), which exhibits the ability to degrade naproxen and ibuprofen, has been reported for the first time.

\section{Materials and Methods}

\subsection{Isolation of Pharmaceuticals Degrading Bacterium}

Non-steroidal anti-inflammatory drugs-degrading strain was isolated from the soil of the chemical factory "Organika-Azot" in Jaworzno, Poland, using the classical enrichment technique with naproxen as a selection factor. The mixed microbial population from the soil was introduced to $0.85 \% \mathrm{NaCl}$ solution and shook at $30{ }^{\circ} \mathrm{C}$ in an aeration chamber. After $3 \mathrm{~h}, 1 \mathrm{ml}$ samples were serially diluted from $10^{-1}$ to $10^{-3}$ with saline and spread onto the agar plates containing mineral salts medium $\left(\mathrm{Na}_{2} \mathrm{HPO}_{4} 12 \mathrm{H}_{2} \mathrm{O} 3.78 \mathrm{~g} ; \mathrm{KH}_{2} \mathrm{PO}_{4} 0.5 \mathrm{~g}\right.$; $\mathrm{NH}_{4} \mathrm{Cl} 5 \mathrm{~g} ; \mathrm{MgSO}_{4} \cdot 7 \mathrm{H}_{2} \mathrm{O}$; per liter of distilled water) with $6 \mathrm{mg} \mathrm{l}^{-1}$ naproxen to obtain pure cultures. The agar plates were incubated at $30{ }^{\circ} \mathrm{C}$ for $24 \mathrm{~h}$ and single colonies were isolated and transferred to the nutrient agar plates to test their purity. Single colonies showing different morphological characteristics were proliferated in a nutrient broth medium (at $30{ }^{\circ} \mathrm{C}$ on a rotary shaker at $130 \mathrm{rpm})$, harvested by centrifugation $(5,000 \times \mathrm{g}$ at $4{ }^{\circ} \mathrm{C}$ for $15 \mathrm{~min}$ ) and washed with fresh sterile mineral salts medium. In order to verify, which strain is able to degrade naproxen and ibuprofen, cultures in a $250-\mathrm{ml}$ flask containing $100 \mathrm{ml}$ of a sterile mineral salts medium supplemented with $6 \mathrm{mg} \mathrm{l}^{-1}$ of naproxen or $20 \mathrm{mg} \mathrm{l}^{-1}$ of ibuprofen were inoculated with previously prepared cells to the final optical density of about $0.8-1.0$ in absorbance scale at $\lambda=600 \mathrm{~nm}$. The cultures were incubated with shaking at $130 \mathrm{rpm}$ at $30{ }^{\circ} \mathrm{C}$, and samples were drawn at regular intervals to monitor growth and naproxen or ibuprofen degradation. The strain able to degrade both naproxen and ibuprofen was kept as a freezing bacterial stock.

\subsection{Morphological, Physiological, and Biochemical Characterization of the Isolated Strain}

The isolated strain was phenotypically and biochemically characterized using standard techniques (Gram staining, colony shape, size, and color on nutrient agar plate, etc.), according to Bergey's Manual of Determinative Bacteriology (Holt et al. 1994). Additional biochemical and physiological characteristics were determined using the API Coryne system (BioMerieux, Lyon, France). Isolation of fatty acids was performed according to Sasser (1990). Analysis of FAMEs was performed using an HP 5890 gas chromatograph (Hewlett Packard, Rolling Meadows, IL, USA) equipped with an HP $25 \mathrm{~m} \times 0.2 \mathrm{~mm}$ cross-linked methyl-silicone capillary column. The initial oven temperature was $170{ }^{\circ} \mathrm{C}$, increased $5{ }^{\circ} \mathrm{C} \mathrm{min}^{-1}$ to $260{ }^{\circ} \mathrm{C}$, the increased $40{ }^{\circ} \mathrm{C} \mathrm{min}{ }^{-1}$ and held constant at $320{ }^{\circ} \mathrm{C}$ for $1.5 \mathrm{~min}$. Helium was used as the carrier gas. Fatty acid methyl esters (FAMEs) were identified with Sherlock software (TSBA library, version 3.9. Microbial ID, Newark, NJ, 
USA) based on the actual calibration retention times run prior to sample analysis.

\subsection{Analytical Methods}

The concentration of non-steroidal anti-inflammatory drugs: ibuprofen, naproxen, paracetamol, and diclofenac (introduced as pharmaceutical substances) were determined with the HPLC technique using Merck Hitachi HPLC reversed-phase chromatograph equipped with a column Ascentis Express ${ }^{\circledR}$ C18 HPLC Column $(100 \times 4.6 \mathrm{~mm})$, pre-column Opti-Solw ${ }^{\circledR} \mathrm{EXP}$, and UV/ VIS DAD detector. The mobile phase consisted of acetonitrile and $1 \%$ acetic acid (50:50 $v / v$ for naproxen, vanillic acid, protocatechuic acid, benzoic acid, and 4hydroxybenzoic acid assay and 5:95 $v / v$ for ibuprofen assay) at a flow rate of $1 \mathrm{ml} / \mathrm{min}$. The mobile phase consisted of acetonitrile, $1 \%$ acetic acid, and methanol (50:30:20 v/v/v for diclofenac assay and 20:60:20 v/v/v for phenol assay) or methanol and $1 \%$ acetic acid $(5: 95 \mathrm{v} / \mathrm{v})$ for paracetamol assay at a flow rate of $1 \mathrm{ml} /$ min. The detection wavelength was set at $260 \mathrm{~nm}$ (naproxen, vanillic acid, protocatechuic acid, benzoic acid, and 4-hydroxybenzoic acid), $240 \mathrm{~nm}$ (ibuprofen and paracetamol), $272 \mathrm{~nm}$ (phenol), and $276 \mathrm{~nm}$ (diclofenac) (Wojcieszyńska et al. 2014). Ibuprofen, naproxen, paracetamol, diclofenac, phenol, vanillic acid, protocatechuic acid, benzoic acid, and 4hydroxybenzoic acid were identified by comparing the HPLC retention times and UV-visible spectra with those of the external standards. The concentration of glucose in the culture supernatant was determined using colorimetric anthrone method (Gerhardt et al. 1994). The concentration of salicylic acid was determined by the method with iron(III) chloride (Poljudek-Fabini and Bejrih 1981).

\subsection{Naproxen and Ibuprofen Degradation Experiments}

Strain B1(2015b) was routinely cultivated in the nutrient broth at $30{ }^{\circ} \mathrm{C}$ and $130 \mathrm{rpm}$ for $24 \mathrm{~h}$. After this, cells were harvested by centrifugation $\left(5,000 \times g\right.$ at $4{ }^{\circ} \mathrm{C}$ for $15 \mathrm{~min}$ ), washed with a fresh sterile medium, and used as inoculum.

Degradation of naproxen or ibuprofen in monosubstrate systems were performed in 500-ml Erlenmeyer flasks containing $250 \mathrm{ml}$ of the mineral salts medium (Greń et al. 2010) inoculated with cells to a final optical density of about 0.8 at $\lambda=600 \mathrm{~nm}$
(OD600). Naproxen was added to obtain a final concentration of $6 \mathrm{mg} \mathrm{l}^{-1}$, and all cultures were incubated with shaking at $30{ }^{\circ} \mathrm{C}$ for 35 days. The chromatographic analyses of the culture fluid and measurements of the cultures growth were carried out every 7 days. For the studies on ibuprofen degradation, strain B1(2015b) was grown in a mineral salts medium supplemented with ibuprofen (concentration range $1-25 \mathrm{mg} \mathrm{l}^{-1}$ ). The residual ibuprofen concentration in the culture filtrates was assayed by liquid chromatography every $24 \mathrm{~h}$.

For studies on the cometabolic degradation of naproxen or ibuprofen, $1 \mathrm{mg} \mathrm{l}^{-1}$ glucose was added. Cultures in $250 \mathrm{ml}$ of sterile mineral salt medium supplemented with glucoses and $6 \mathrm{mg}^{-1}$ naproxen or 1$25 \mathrm{mg} \mathrm{l}^{-1}$ ibuprofen were inoculated with cells to a final optical density of about 0.1 at $\lambda=600 \mathrm{~nm}$ (OD600) and incubated at $30{ }^{\circ} \mathrm{C}$ with shaking at $130 \mathrm{rpm}$. If the complete degradation of the suitable growth substrate was observed, a successive dose of glucose was introduced and the culture was left for incubation until it reached $\mathrm{OD}_{600}=1.0$. All cultures were grown in triplicates.

Additionally, control cultures $(250 \mathrm{ml})$ for each drug were prepared: an uninoculated control consisted of the mineral salts medium only (abiotic degradation control), and a heat-killed control consisted of bacterial cells destroyed by autoclaving (adsorption onto biomass control). The optical density of the heat-killed control was the same as for the examined cultures.

\subsection{Phylogenetic Analysis}

Bacterial DNA was isolated from the pure culture using the DNA commercial kit (GenElute Bacterial Genomic DNA Kit, Sigma-Aldrich). For 16S rRNA gene amplification, the bacteria-specific primers: $8 \mathrm{~F} 5^{\prime}$ AgtTtGatCATCGCTCAG 3' and 1492R 5' GGTTACCTTGTTACGACTT3' were used. Amplification was carried out through a program consisting of initial denaturation at $94{ }^{\circ} \mathrm{C}$ for $300 \mathrm{~s}$, three cycles at $94{ }^{\circ} \mathrm{C}$ for $45 \mathrm{~s}, 57^{\circ} \mathrm{C}$ for $30 \mathrm{~s}$, and $72{ }^{\circ} \mathrm{C}$ for $120 \mathrm{~s}$; three cycles at $94{ }^{\circ} \mathrm{C}$ for $45 \mathrm{~s}, 56{ }^{\circ} \mathrm{C}$ for $30 \mathrm{~s}$, and $72{ }^{\circ} \mathrm{C}$ for $120 \mathrm{~s}$; three cycles at $94^{\circ} \mathrm{C}$ for $45 \mathrm{~s}, 55^{\circ} \mathrm{C}$ for $30 \mathrm{~s}$, and $72{ }^{\circ} \mathrm{C}$ for $120 \mathrm{~s} ; 26$ cycles at $94{ }^{\circ} \mathrm{C}$ for $45 \mathrm{~s}, 53^{\circ} \mathrm{C}$ for $30 \mathrm{~s}$, and $72{ }^{\circ} \mathrm{C}$ for $120 \mathrm{~s}$; and a final elongation step at $72{ }^{\circ} \mathrm{C}$ for $300 \mathrm{~s}$. The nucleotide sequencing of the gene was done by using the Big Dye ${ }^{\mathrm{R}}$ Terminator Cycle Sequencing Kit (Applied Biosystem) and AbiPrism ${ }^{\circledR} 3100$ Genetic Analyzer. The MegaBLAST 
Table 1 Differential phenotypic characteristics of strain B1(2015b)

\begin{tabular}{l} 
Characteristic \\
\hline Growth in the absence of $\mathrm{N}$ \\
Growth in the presence of 1.5 \\
$(w / v) \mathrm{NaCl}$ \\
Growth in the presence of 3 \\
$(w / v) \mathrm{NaCl}$ \\
Growth at $4{ }^{\circ} \mathrm{C}$ \\
Growth at $20^{\circ} \mathrm{C}$ \\
Growth at $30{ }^{\circ} \mathrm{C}$ \\
Growth at $42{ }^{\circ} \mathrm{C}$ \\
Oxidase \\
Catalase \\
Hydrolysis of esculin \\
Hydrolysis of gelatin \\
Arginine dihydrolase \\
Urease \\
Indol production \\
Nitrate reduction \\
Pyrazinamidase \\
Pyrrolidonyl arylamidase \\
Alkaline phosphatase \\
$\beta$-Glucuronidase \\
$\beta$-Galactosidase \\
$\alpha$-Glucosidase \\
-
\end{tabular}

$\mathrm{N}$-acetyl- $\beta$-glucosaminidase

Assimilation of:

\section{Glucose}

Arabinose

Mannose

Mannitol

Maltose

Gluconate

Caprate

Adipate

Malate

Citrate

Phenylacetate

$\mathrm{N}$-acetyl-glucosamine

Fermentation of:

Glucose

Ribose

Xylose

Mannitol

Maltose

Lactose
Table 1 (continued)

\begin{tabular}{ll}
\hline Characteristic & Results \\
\hline Saccharose & - \\
Glycogen & - \\
\hline+ positive reaction, - negative reaction &
\end{tabular}

+ positive reaction, - negative reaction

program was used for homology searches with the standard default program. Multiple sequence alignments were performed and the neighbor-joining phylogenetic tree was constructed using CLC Sequence Viewer 7.0.2 program. The $16 \mathrm{~S}$ rRNA gene sequence determined in this study has been deposited in the GeneBank database of NCBI under the accession number KP895873.1.

\section{Results and Discussion}

3.1 Isolation and Identification of Strain that Degrades Aromatic Compounds

Until now, only a few strains have been isolated and characterized as naproxen or ibuprofen degraders. The ability to degrade ibuprofen was shown for Sphingomonas sp. Ibu-2 and Variovorax Ibu-1 (Murdoch and Hay 2005,

Table 2 Percentage of total fatty acid from Bacillus thuringiensis B1(2015b)

\begin{tabular}{|c|c|}
\hline Fatty acids & $\%$ of total fatty acids \\
\hline \multicolumn{2}{|l|}{ Saturated } \\
\hline $14: 0$ & $0.21 \pm 0.011$ \\
\hline $16: 0$ & $9.09 \pm 0.218$ \\
\hline $17: 0$ & $0.28 \pm 0.025$ \\
\hline $18: 0$ & $4.58 \pm 0.24$ \\
\hline $18: 02 \mathrm{OH}$ & $0.34 \pm 0.02$ \\
\hline 18:0 anteiso & $47.42 \pm 0.26$ \\
\hline 19:0 iso & $0.31 \pm 0.05$ \\
\hline 20:0 & $0.19 \pm 0.00$ \\
\hline \multicolumn{2}{|l|}{ Unsaturated } \\
\hline $16: 1 \omega 7 \mathrm{c}$ & $0.19 \pm 0.03$ \\
\hline $17: 1 \omega 8 \mathrm{c}$ & $0.16 \pm 0.00$ \\
\hline $18: 1 \omega 9 \mathrm{c}$ & $37.46 \pm 0.13$ \\
\hline Sat./unsat. ratio & 0.18 \\
\hline
\end{tabular}

-OH indicates the position of hydroxyl group from the acid end $\omega$ methyl end of fatty acid, $c$ cis configuration of the double bound, iso anteiso-branched fatty acids 


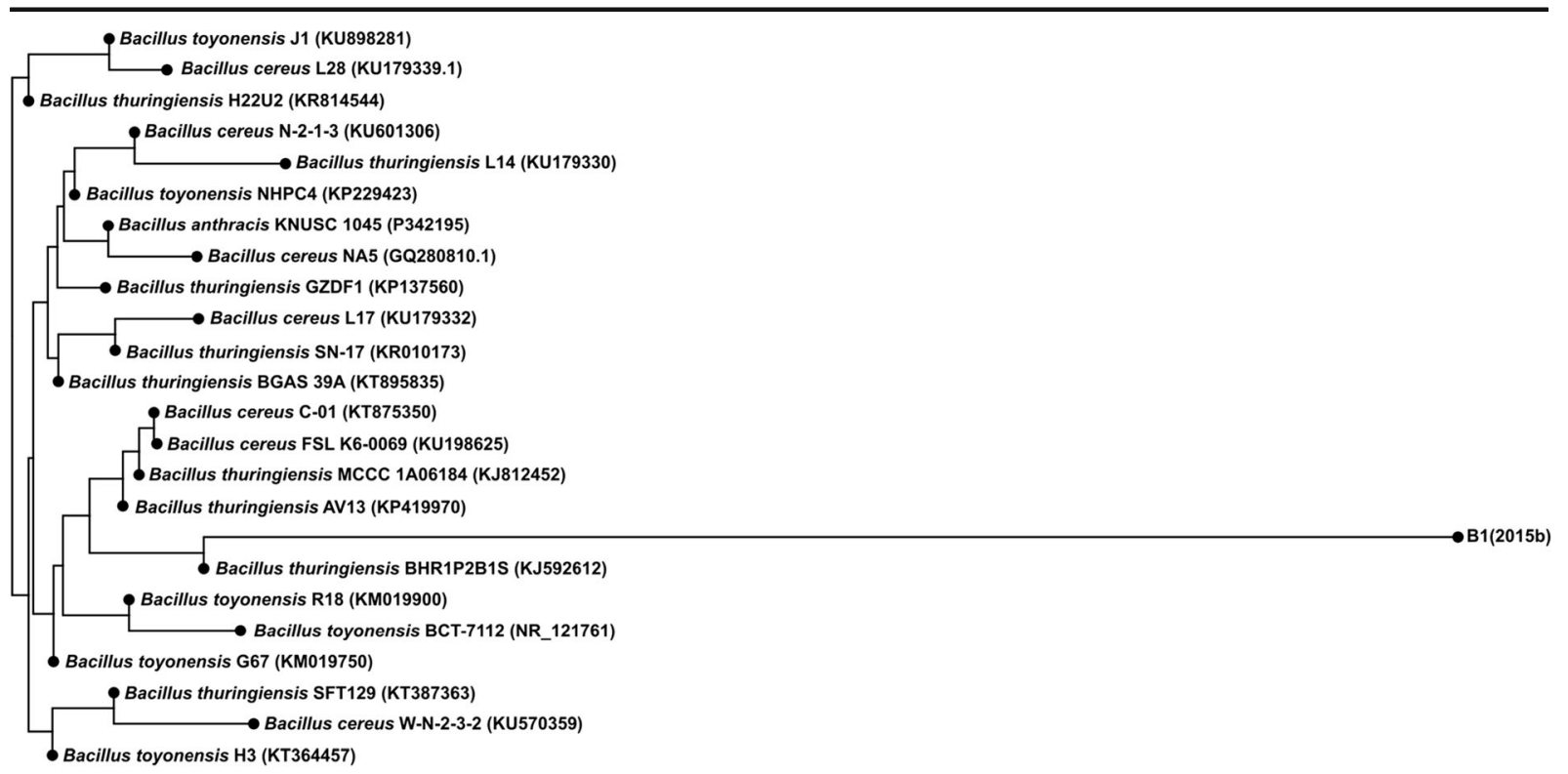

0.002

Fig. 1 Neighbor-joining tree showing the phylogenetic position of the non-steroidal anti-inflammatory-degrading bacterium strain B1(2015b) and selected and related species of the genus Bacillus

2015) as well as for Patulibacter sp. strain I11 (Almeida et al. 2013). The only strain able to degrade naproxen is Stenotrophomonas maltophilia KB2, which degrades this compound under cometabolic conditions (Wojcieszyńska et al. 2014). However, a bacterial strain that would have shown the ability to degrade both ibuprofen and naproxen has not yet been described.

The strain marked as B1(2015b), which was isolated from the soil of the chemical factory "Organika-Azot" in Jaworzno, Poland, is a Gram-positive rod-shaped based on partial 16S rRNA gene sequences. The GenBank accession number for each microorganism used in the analysis is shown in parentheses after the species name

bacterium able to utilize two of the five most commonly used non-steroidal anti-inflammatory drugs: ibuprofen and naproxen. In contrast, the strain is not capable of degrading salicylic acid, acetaminophen, and diclofenac. Moreover, this strain is able to use various aromatic compounds as a carbon and energy source: phenol, vanillic acid, protocatechuic acid, benzoic acid, and 4-hydroxybenzoic acid. Microbiological and biochemical characterization of the strain revealed that it is aerobic, oxidase, and catalase positive (Table 1).
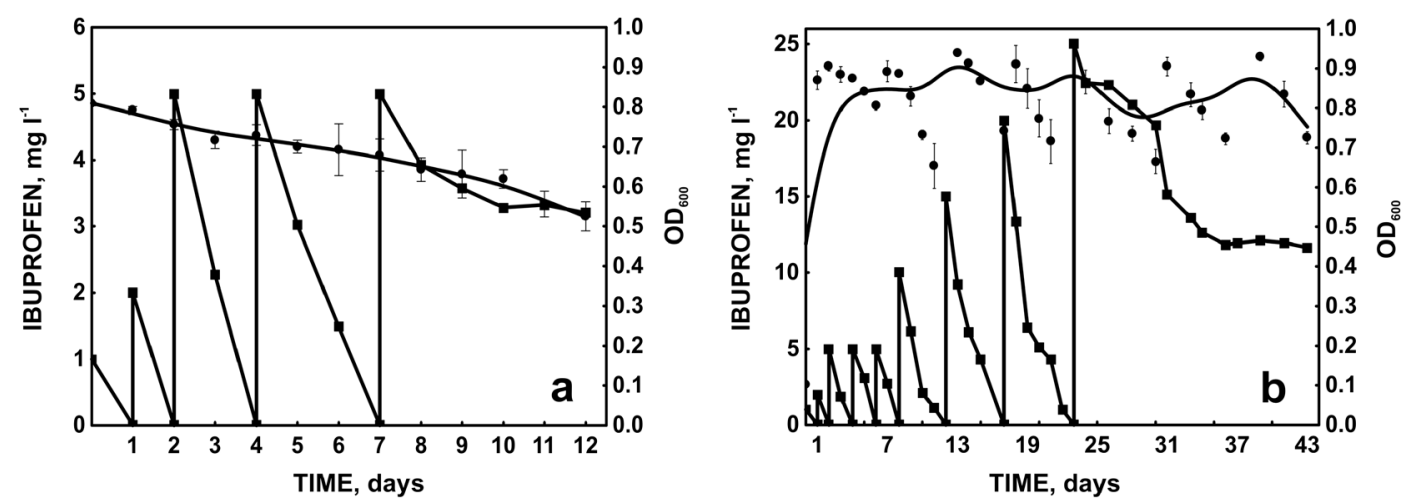

, Substrate; O, Optical density

Fig. 2 The adaptation of Bacillus thuringiensis B1(2015b) to increasing concentration of ibuprofen and changes of microbial biomass monitored as optical density at 600 (a without additional carbon source; $\mathbf{b}$ with $1 \mathrm{ml} \mathrm{mg} 1^{-1}$ glucose as a simple carbon source) 

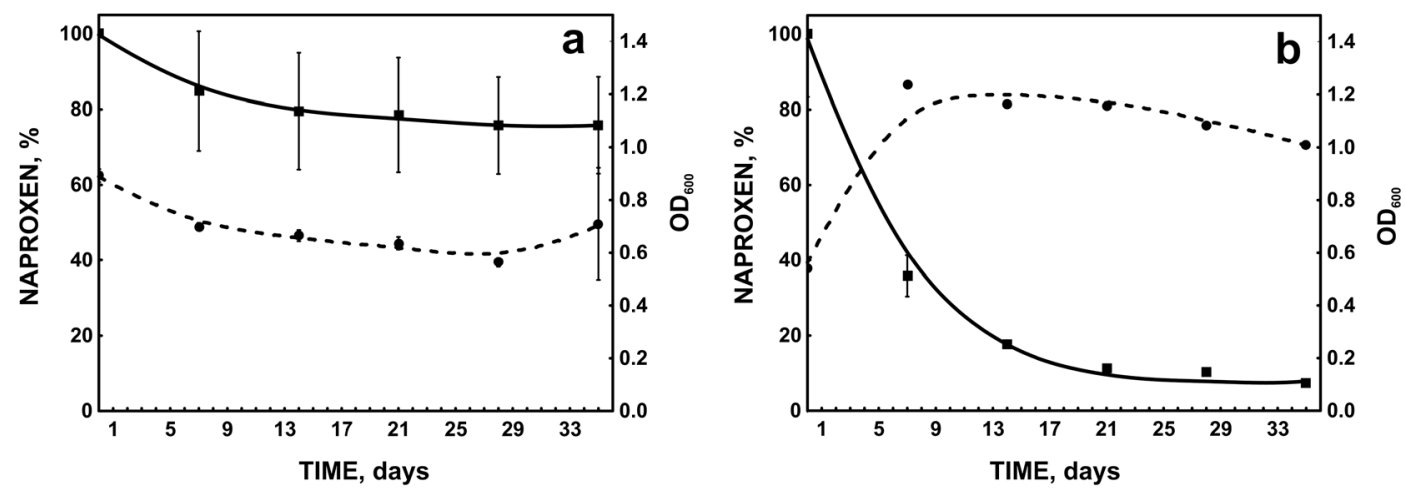

口, Substrate; Optical density

Fig. 3 Degradation of $6 \mathrm{mg} \mathrm{l}^{-1}$ naproxen by strain B1(2015b) and changes of microbial biomass monitored as optical density at $600 \mathrm{~nm}$ (a without additional carbon source; $\mathbf{b}$ with $1 \mathrm{ml} \mathrm{mg} \mathrm{l}^{-1}$ glucose as a simple carbon source)

Colonies of strain B1(2015b) were found to be circular, smooth, convex, and cream-colored. The biochemical and physiological characteristics of strain B1(2015b) are summarized in Table 1 . The analysis of the fatty acid profile showed significant contents of 18:0 anteiso and 16:0 and 18:0 fatty acids (Table 2). It is known that straight and branched chain fatty acids are biomarkers of Gram-positive bacteria (Piotrowska-Seget and Mrozik 2003). However, we also observed an unusual amount of $18: 1 \omega 9 \mathrm{c}$ fatty acids. These results coincide with the results obtained by $\mathrm{Li}$ et al. (2010) who observed $30.96 \%$ of $18: 1$ fatty acids in Bacillus subtilis. Partial sequence analysis of the $16 \mathrm{~S}$ rRNA gene allows classifying the isolate with $98 \%$ similarity as a member of the genus Bacillus. Comparison of the 16S rDNA gene sequence of the isolate with the $16 \mathrm{~S}$ rDNA gene sequences of bacteria identified to a species level showed that selected strain belongs to the species Bacillus thuringiensis (Fig. 1). In accordance with these data, the isolate B1(2015b) was included in the genus Bacillus and named as Bacillus thuringiensis sp. B1(2015b).

\subsection{Degradation of Ibuprofen and Naproxen by Strain B1(2015b)}

It is the first report on Gram-positive bacterium that is able to degrade both naproxen and ibuprofen. The described strain was isolated from a post-industrial landfill site belonging to a chemical factory which has produced veterinary drugs, hygiene products, and pesticides since 1928. It caused contamination of the surrounding area by cyanides, heavy metals, and pesticides such as dieldrin, endrin, $\alpha$-, $\beta$-, and $\gamma$-hexachlorocyclohexane, phenols, hexachlorobenzene, dichlorodiohenyltrichloroethane (DDT), dichlorodiphenyldichloroethylene (DDE), and dichlorodiphenyldichloroethane (DDD). These contaminations probably influence the adaptation of microflora in this area. That is why we could assume that it is a good source of microorganisms able to degrade different aromatic compounds. The bacterium isolated during this study was classified as a Bacillus. It is known that Gram-positive bacteria, including the $B a$ cillus species, are tolerant to many toxic compounds such as phenols, policyclic aromatic hydrocarbons, heavy metals, and different organic solvents. The high tolerance to different factors is connected with the structure of cellular membranes, synthesis of the surface active agents, and specific enzymes (Satchanska et al. 2006; Trivedi et al. 2011; Solyanikova et al. 2014; Swaathy et al. 2014).

The isolated strain, Bacillus thuringiensis $\mathrm{B1}(2015 \mathrm{~b})$, exhibits the ability to degrade $5 \mathrm{mg} \mathrm{l}^{-1}$ of ibuprofen within 2 days (Fig. 2a) and small amounts of naproxen (Fig. 3a). However, we observed a decrease in the optical density of bacterial cultures (Figs. 2a and 3a). It indicates that these compounds are not a sufficient carbon source. It is known that an additional carbon source may enhance the degradation capability of the strain by increasing the biomass (Zhong et al. 2007; Zhang et al. 2009). Quintana et al. (2005) observed the intensification of naproxen and ibuprofen degradation by active sludge in the presence of powdered milk used as a growth substrate. In this study, glucose was used as a carbon and energy source. It resulted in the significant improvement of NSAIDs' degradation activity of the examined strain. Simultaneously, the decrease of the biomass was not observed. Under this condition, strain 
$\mathrm{B} 1(2015 \mathrm{~b})$ was adapted to the degradation of $20 \mathrm{mg}^{-1}$ of ibuprofen within 6 days. However, $46.56 \%$ of $25 \mathrm{mg} /$ 1 of ibuprofen was degraded by this strain during 20 days (Fig. 2b).

Murdoch and Hay $(2005,2015)$ also described bacterial strains Sphingomonas Ibu-2 and Variovorax Ibu-1 able to degrade ibuprofen at high concentration. However, Bacillus thuringiensis B1(2015b) was additionally able to totally degrade $6 \mathrm{mg}^{-1}$ of naproxen within 35 days (Fig. 3b). Complete degradation of naproxen by a pure bacterial strain has not yet been observed. The described Stenotrophomonas maltophilia strain KB2 degraded $78 \%$ of $6 \mathrm{mg}^{-1}$ of naproxen in the presence of glucose (Wojcieszyńska et al. 2014).

To conclude, bacterial strain isolated from the soil of the chemical factory "Organika-Azot" in Jaworzno, Poland, was identified as Bacillus thuringiensis B1(2015b). This strain showed the ability to degrade $20 \mathrm{mg}^{-1}$ of ibuprofen during 6 days and $6 \mathrm{mg} \mathrm{l}^{-1}$ of naproxen during 5 weeks under cometabolic condition. Because of these facts, Bacillus thuringiensis $\mathrm{B} 1(2015 \mathrm{~b})$ may play a key role in the bioremediation of NSAIDs-contaminated environments.

Acknowledgments This work was financed by the National Science Centre (Poland), granted on the basis of decision DEC2013/09/B/NZ9/00244. We thank Dr Renata Zub (Department of Molecular Biology, Institute of Oncology, Warsaw, Poland) for DNA sequencing.

Open Access This article is distributed under the terms of the Creative Commons Attribution 4.0 International License (http:// creativecommons.org/licenses/by/4.0/), which permits unrestricted use, distribution, and reproduction in any medium, provided you give appropriate credit to the original author(s) and the source, provide a link to the Creative Commons license, and indicate if changes were made.

\section{References}

Ahmed, S., Javed, M. A., Tanvir, S., \& Hameed, A. (2001). Isolation and characterization of a Pseudomonas strain that degrades 4-acetamidophenol and 4-aminophenol. Biodegradation, 12, 303-309.

Almeida, B., Kjeldal, H., Lolas, I., Knudsen, A. D., Carvalho, G., Nielsen, K. L., et al. (2013). Quantitative proteomic analysis of ibuprofen-degrading Patulibacter sp. strain I11. Biodegradation, 24, 615-630.

Chen, Y., \& Rosazza, J. P. N. (1994). Microbial transformation of ibuprofen by a Nocardia species. Applied and Environmental Microbiology, 60, 1292-1296.

Domaradzka, D., Guzik, U., \& Wojcieszyńska, D. (2015). Biodegradation and biotransformation of polycyclic non- steroidal anti-inflammatory drugs. Reviews in Environmental Science and Biotechnology, 14, 229-239.

Gerhardt, P., Murray, R. G. E., Wood, W. A., \& Krieg, N. R. (1994). Methods for general and molecular bacteriology. Washington DC: ASM. 1-55581-048-9.

Greń, I., Wojcieszyńska, D., Guzik, U., Perkosz, M., \& HupertKocurek, K. (2010). Enhanced biotransformation of mononitrophenols by Stenotrophomonas maltophilia KB2 in the presence of aromatic compounds of plant origin. World Journal of Microbiology and Biotechnology, 26, 289-295.

Grenni, P., Patrolecco, L., Ademollo, N., Tolomei, A., \& Caracciolo, A. B. (2013). Degradation of gemfibrozil and naproxen in a river water ecosystem. Microchemical Journal, 107, 158-164.

Holt, J. G., Krieg, N. R., Sneath, P. H. A., Staley, J. T., \& Williams, S. T. (1994). Bergey's manual of determinative bacteriology. USA: Williams and Wilkins.

Jeffries, K. M., Brander, S. M., Britton, M. T., Fangue, N. A., \& Connon, R. E. (2015). Chronic exposure to low and high concentration of ibuprofen elicit different gene response patterns in a euryhaline fish. Environmental Science and Pollution Research, 22, 17397-17413.

Lahti, M., \& Oikari, A. (2011). Microbial transformation of pharmaceuticals naproxen, bisprolol, and diclofenac in aerobic and anaerobic environments. Archives of Environmental Contamination and Toxicology, 61, 202-210.

Li, Y., Wu, S., Wang, L., Li, Y., Shi, F., \& Wang, X. (2010). Differentiation of bacteria using fatty acid profiles from gas chromatography - tandem mass spectrometry. Journal of the Science of Food and Agriculture, 90, 1380-1383.

Li, F. H., Yao, K., Lv, W. Y., Liu, G. G., Chen, P., Huang, H. P., \& Kang, Y. P. (2015a). Photodegradation of ibuprofen under UV-vis irradiation: mechanism and toxicity of photolysis products. Bulletin of Environmental Contamination and Toxicology, 94, 479-483.

Li, X., Toledo, R. A., Wang, S., \& Shim, H. (2015b). Removal of carbamazepine and naproxen by immobilized Phanerochaete chrysosporium under non-sterile condition. New Biotechnology, 32, 282-289.

Marotta, R., Spasiano, D., Di Somma, I., \& Andreozzi, A. (2013). Photodegradation of naproxen and its photoproducts in aqueous solution at $254 \mathrm{~nm}$ : a kinetic investigation. Water Research, 47, 373-383.

Murdoch, R. W., \& Hay, A. G. (2005). Formation of catechols via removal of acid side chains from ibuprofen and related aromatic acid. Applied and Environmental Microbiology, 71, 6121-6125.

Murdoch, R. W., \& Hay, A. G. (2015). The biotransformation of ibuprofen to trihydroxyibuprofen in activated sludge and by Variovorax Ibu-1. Biodegradation, 26, 105-113.

Nikolaou, A., Meric, S., \& Fatta, D. (2007). Occurrence patterns of pharmaceuticals in water and wastewater environments. Analytical and Bioanalytical Chemistry, 387, 1225-1234.

Piotrowska-Seget, Z., \& Mrozik, A. (2003). Signature lipid biomarker (SLB) analysis in determining changes in community structure of soil microorganisms. Polish Journal of Environmental Studies, 12, 669-675.

Poljudek-Fabini, R., \& Bejrih, T. (1981). Organicheskij analiz (p. 622). Leningrad: Himija (in Russian). 
Quintana, J. B., Weiss, S., \& Reemtsma, T. (2005). Pathways and metabolites of microbial degradation of selected acidic pharmaceutical and their occurrence in municipal wastewater treated by a membrane bioreactor. Water Research, 39, 2654-2664.

Rodarte-Morales, A. I., Feijoo, G., Moreira, M. T., \& Lema, J. M. (2011). Degradation of selected pharmaceutical and personal care products (PPCPs) by white-rot fungi. World Journal of Microbiology and Biotechnology, 27, 1839-1849.

Rodriguez-Rodriguez, C. E., Marco-Urrea, E., \& Caminal, G. (2010). Degradation of naproxen and carbamazepine in spiked sludge by slurry and solid-phase Trametes versicolor systems. Bioresource Technology, 101, 2259-2266.

Sasser, M. (1990). Technical note \#, 101-110.

Satchanska, G., Topalova, Y., Ivanov, I., \& Golovinsky, E. (2006). Xenobiotic biotransformation potential of Pseudomonas rhodesiae $\mathrm{KCM}-\mathrm{R}_{5}$ and Bacillus subtilis $\mathrm{KCM}-\mathrm{RG}_{5}$, tolernat to heavy metals and phenol derivatives. Biotechnology \& Biotechnological Equipment, 20, 97-102.

Solyanikova, I. P., Robota, I. V., Mazur, D. M., Lebedev, A. Y., \& Golovleva, L. A. (2014). Application of Bacillus sp. strain VT-8 for decontamination of TNT-polluted sites. Microbiology, 83, 577-584.

Styszko, K., Sosnowska, K., Wojtanowicz, P., Gołaś, J., Górecki, J., \& Macherzyński, M. (2010). Sorption of ibuprofen on sediments from the Dobczyce (southern Poland) drinking water reservoir. Archives of Environmental Protection, 36, 81-91.

Swaathy, S., Kavitha, V., Pravin, A. S., Mandal, A. B., \& Gnanamani, A. (2014). Microbial surfactant mediated degradation of anthracene in aqueous phase by marine Bacillus licheniformis MTCC5514. Biotechnology Reports, 4, 161-170.

Trivedi, N., Gupta, V., Kumar, M., Kumari, P., Reddy, C. R. K., \& Jha, B. (2011). Solvent tolerant marine bacterium Bacillus aquimaris secreting organic solvent stable alkaline cellulase. Chemosphere, 83, 706-712.

Wojcieszyńska, D., Domaradzka, D., Hupert-Kocurek, K., \& Guzik, U. (2014). Bacterial degradation of naproxen - undisclosed pollutant in the environment. Journal of Environmental Management, 145, 157-161.

Wu, S., Zhang, L., \& Chen, J. (2012). Paracetamol in the environment and its degradation by microorganism. Applied Microbiology and Biotechnology, 96, 875-884.

Yu, J. T., Bouwer, E. J., \& Coelhan, M. (2006). Occurrence and biodegradability studies of selected pharmaceuticals and personal care products in sewage effluent. Agricultural Water Management, 86, 72-80.

Zhang, G., Yang, X., Xie, F., Chao, Y., \& Qian, S. (2009). Cometabolic degradation of mono-chloro benzoic acids by Rhodococcus sp. R04 grown on organic carbon sources. World Journal of Microbiology and Biotechnology, 25, 1169-1174.

Zhong, Y., Luan, T., Wang, X., Lan, C. H., \& Tam, N. F. Y. (2007). Influence of growth medium on cometabolic degradation of polycyclic aromatic hydrocarbons by Sphingomonas sp. strain PheB4. Applied Microbiology and Biotechnology, 75, 175-186. 